Abstracta Iranica Iranica

Revue bibliographique pour le domaine irano-aryen

Volume 32-33 | 2013

Comptes rendus des publications de 2009-2010

\title{
Bruno Overlaet. A Roman Emperor at Bishapur and Darabgird: Uranius Antoninus and the black stone of Emesa
}

Barbara Kaim

\section{(2) OpenEdition}

1 Journals

Édition électronique

URL : http://journals.openedition.org/abstractairanica/40566

DOI : 10.4000/abstractairanica.40566

ISSN : 1961-960X

\section{Éditeur :}

CNRS (UMR 7528 Mondes iraniens et indiens), Éditions de l'IFRI

\section{Édition imprimée}

Date de publication : 1 décembre 2013

ISSN : 0240-8910

Référence électronique

Barbara Kaim, «Bruno Overlaet. A Roman Emperor at Bishapur and Darabgird: Uranius Antoninus and the black stone of Emesa », Abstracta Iranica [En ligne], Volume 32-33 | 2013, document 195, mis en ligne le 01 juillet 2016, consulté le 03 octobre 2020. URL : http://journals.openedition.org/abstractairanica/ 40566 ; DOI : https://doi.org/10.4000/abstractairanica.40566

Ce document a été généré automatiquement le 3 octobre 2020.

Tous droits réservés 


\title{
Bruno Overlaet. A Roman Emperor at Bishapur and Darabgird: Uranius Antoninus and the black stone of Emesa
}

\author{
Barbara Kaim
}

\section{RÉFÉRENCE}

Bruno Overlaet. «A Roman Emperor at Bishapur and Darabgird: Uranius Antoninus and the black stone of Emesa ». Iranica Antiqua, 44, 2009, p. 461-530.

1 L'A. suggère la possibilité que le relief Bishapur III (et aussi Bishapur II et Darabgird) commémore une campagne syrienne de Shapur I menée en 253 AD. Un objet oval apporté au roi Shapur I par une délégation est identifié comme la pierre noire d'Émèse, un célèbre bétyle. Une piste intéressante, mais qui exige un argument plus fort pour expliquer pourquoi ce présumé bétyle est représenté deux fois: il figure aussi sur le $2^{\mathrm{e}}$ registre du relief porté par un Romain et sur le 4ème registre, il est suspendu à un poteau par deux sangles et porté par deux hommes en costume iranien. Cette fois il est plus petit. L'analogie avec les scènes des chasses royales sassanides où un animal peut être représenté deux fois dans la même scène, pourchassé et tué, semble être incomplète parce que dans ce cas, les animaux sont montrés comme identiques. 


\section{AUTEURS}

\section{BARBARA KAIM}

Université de Varsovie 